\title{
Changzhou Sinotype Technology Co., Ltd, Hague Service Convention and Judgment Enforcement in China
}

Jie (Jeanne) Huang, University of Sydney Law School, Australia

Changzhou Sinotype Technology Co, Ltd. v. Rockefeller Technology Investments (Asia) VII is a recent case decided by the Supreme Court of California on April 2, 2020. The certiorari to the Supreme Court of the US was denied on 5 October 2020. It is a controversial case concerning the interpretation of the Convention on the Service Abroad of Judicial and Extra Judicial Documents in Civil or Commercial Matters of November 15, 1965 (the "Hague Service Convention") for service of process in China.

\section{Facts:}

Changzhou SinoType Technology Co. (SinoType) is based in China. Rockefeller Technology Investments (Asia) VII (Rockefeller) is an American investment firm. In February 2008, they signed a memorandum of understanding (MOU) which provided that:

"6. The parties shall provide notice in the English language to each other at the addresses set forth in the Agreement via Federal Express or similar courier, with copies via facsimile or email, and shall be deemed received 3 business days after deposit with the courier.

7. The Parties hereby submit to the jurisdiction of the Federal and State courts in California and consent to service of process in accord with the notice provisions above.

8. In the event of any disputes arising between the Parties to this Agreement, either Party may submit the dispute to the Judicial Arbitration \& Mediation Service in Los Angeles for exclusive and final resolution pursuant to according 
to [sic] its streamlined procedures before a single arbitrator who shall have ten years judicial service at the appellate level, pursuant to California law, and who shall issue a written, reasoned award. The Parties shall share equally the cost of the arbitration. Disputes shall include failure of the Parties to come to Agreement as required by this Agreement in a timely fashion."

Due to disputes between the parties, in February 2012, Rockefeller brought an arbitration against SinoType. SinoType was defaulted in the arbitration proceeding. According to the arbitrator, SinoType was served by email and Federal Express to the Chinese address listed for it in the MOU. In November 2013, the arbitrator found favorably for Rockefeller.

Instead of enforcing the award in China according to the New York Convention,[1] Rockefeller petitioned to confirm the award in State courts in California. Cal. Civ. Proc. Code § 1290.4(a) provides that a petition to confirm an arbitral award "shall be served in the manner provided in the arbitration agreement for the service of such petition and notice." Therefore, Rockefeller transmitted the summons and its petition to SinoType again through FedEx and email according to paragraph 7 of the MOU. SinoType did not appear and the award was confirmed in October 2014. SinoType then appeared specially and applied to set aside the judgment. It argued that the service of the Californian court proceeding did not comply with the Hague Service Convention; therefore, it had not been duly served and the judgment was void.

\section{Decision}

The California Supreme Court rejected SinoType's argument.

The Court discerned three principles for the application of the Hague Service Convention. First, the Convention applies only to "service of process in the technical sense" involving "a formal delivery of documents". The Court distinguished "service" and "notice" by referring to the Practical Handbook on the Operation of the Service Convention, published by the Permanent Bureau of the Hague Conference on Private International Law ('Handbook'). The Court cited that

"the Convention cannot-and does not-determine which documents need to be served. It is a matter for the lex fori to decide if a document needs to be served 
and which document needs to be served. Thus, if the law of the forum states that a notice is to be somehow directed to one or several addressee(s), without requiring service, the Convention does not have to be applied."[2]

Second, the law of the sending forum (i.e. the law of California) should be applied to determine whether "there is occasion to transmit a judicial or extrajudicial document for service abroad."

Third, if formal service of process is required under the law of the sending forum, the Hague Convention must be complied for international transmission of service documents.

The court held that the parties have waived the formal service of process, so the Hague Service Convention was not applicable in this case.[3]

\section{Comments}

The Changzhou Sinotype Technology Co, Ltd has a number of interesting aspects and has been commented such as here, here and here.

First, the Hague Service Convention is widely considered as 'non-mandatory' but 'exclusive'.[4] Addressing the non-mandatory nature of the Convention, the Handbook states that "the Convention can not-and does not-determine which documents need to be served. It is a matter for the lex fori to decide if a document needs to be served and which document needs to be served."[5] However, this statement does not necessarily mean, when judicial documents are indeed transmitted from a member state to another to charge a defendant with notice of a pending lawsuit, a member state can opt out of the Convention by unilaterally excluding the transmission from the concept of service. Volkswagen Aktiengesellschaft $v$ Schlunk decided by the Supreme Court of the US and Segers and Rufa BV v. Mabanaft $G m b H$ decided by the Supreme Court of the Netherlands (Hoge Raad) are the two most important cases on the non-mandatory nature of the Convention. Both cases concentrate on which law should be applied to whether a document needed to be transmitted abroad for service.[6] However, Rockefeller is different because it is about which law should be applied to determine the concept of service when the transmission of judicial documents takes place in the soil of another member state. The Handbook provides that the basic criterion for the Convention to apply is "transmission abroad" and "place of 
service is determining factor".[7] When judicial documents are physically transmitted in the soil of a member state, allowing another member state to unilaterally determine the concept of service in order to exclude the application of the Convention will inappropriately expand the non-mandatory character of the Convention. This will inevitably narrow the scope of the application of the Convention and damage the principle of reciprocity as the foundation of the Convention. The Hague Convention should be applied to Rockefeller because the summons and petitions were transmitted across border for service in China.

Second, as part of its accession to the Hague Convention, China expressly stated that it does not agree to service by mail. Indeed, the official PRC declarations and reservations to the Hague Convention make it clear that, with the limited exception of voluntary service on a foreign national living in China by his country's own embassy or consulate, the only acceptable method of service on China is through the Chinese Central Authority. Therefore, although China has recognized monetary judgments issued in the US according to the principle of reciprocity, the judgment of Changzhou Sinotype Technology Co, Ltd probably cannot be recognized and enforced in China.

The California Supreme Court decision has important implications. For Chinese parties who have assets outside of China, they should be more careful in drafting their contracts because Changzhou Sinotype Technology Co, Ltd shows that a US court may consider their agreement on service by post is a waiver of China's reservation under the Hague Service Convention. For US parties, if Chinese defendants only have assets in China for enforcement, Changzhou Sinotype Technology Co, Ltd is not a good case to follow because the judgment probably cannot be enforced in China.

[1] China is a party to the Convention on the Recognition and Enforcement of Foreign Arbitral Awards, Jun. 10, 1958, 21 U.S.T. 2517, 330 U.N.T.S. 38 ("New York Convention").

[2] Practical Handbook on the Operation of the Service Convention (4th ed. 2016) par. 54, p. 23, fn. Omitted. 
[3] The Court emphasized that their conclusions should be limited to Section 1290.4, subdivision (a): "Our conclusions as to California law are narrow. When parties agree to California arbitration, they consent to submit to the personal jurisdiction of California courts to enforce the agreement and any judgment under section 1293. When the agreement also specifies the manner in which the parties "shall be served," consistent with section 1290.4, subdivision (a), that agreement supplants statutory service requirements and constitutes a waiver of formal service in favor of the agreed-upon method of notification. If an arbitration agreement fails to specify a method of service, the statutory service requirements of section 1290.4, subdivisions (b) or (c) would apply, and those statutory requirements would constitute formal service of process. We express no view with respect to service of process in other contexts."

[4] Martin Davies et al., Nygh's Conflict of Laws in Australia 36 (10th ed. 2020).

[5] Paragraph 54 of the Handbook.

[6] Ibid., paragraphs 31-45, and 47.

[7] Ibid., paragraph 16. 